The 3rd International Conference on Biological Science 2013

(The 3rd ICBS-2013)

\title{
IDENTIFICATION OF JAVAN LANGUR (Trachypithecus auratus) IN JAVAN LANGUR CENTER (JLC) COBAN TALUN-BATU BASED ON D-LOOP SEQUENCES
}

\author{
Anisa Rizkyani ${ }^{1}$, Elizabeth Marlynda Shierly Sai', Miftahul Muslih², Abdul Ghofur ${ }^{1}$, \\ and Dwi Listyorini ${ }^{1}$

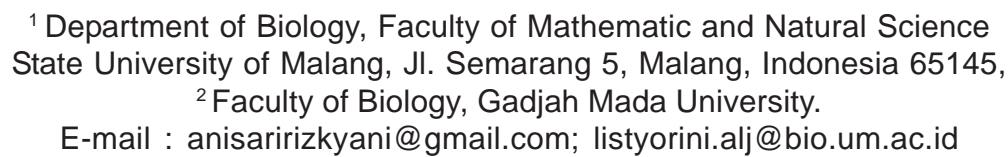

\begin{abstract}
Javan Langur (Trachypithecus auratus) is one of endemic primates in Indonesia and classified into vulnerable level. Based on its morphological characteristic and geographic area, Javan Langur divided into 2 subspecies, those are Trachypithecus auratus auratus and Trachypithecus auratus mauritius. The identification of its morphological characteristic and genetic in species or subspecies level is important before releasing because it is correlated with inbreeding grouping and releasing place. The aim of this study is to identify the Javan Langur (Trachypithecus auratus) in Javan Langur Center (JLC) Coban Talun-Batu based on D-Loop sequence. The blood sample used in this study was taken from two adult female Javan Langur named ljem and Embun, that have different morphological characteristics. Both (primates) are suggested to be T.a.mauritius and T.a.auratus respectively. The amplification of $D$-Loop sequence by mean of PCR technique was performed using specific designed primers forward D-LoopRs 5'-GTACTTAACTCCACCACCAA-3' and reverse D-LoopRs 5'-GTTGAGTTGGGTATGCTCGA-3'. The phylogenetic tree reconstruction based on MEGA 5 using Maximum Likelihood (ML) method and pairwise distance analysis with Kimura-2 parameter model shows that ljem and Embun are placed in different clade. Pairwise distance from those samples value is $11,4 \%$, it prove that they are interspecies. This result supports the morphological characteristic and previous research used $C y t-b$ sequence, ljem is Trachypithecus auratus mauritius and Embun is Trachypithecus auratus auratus.
\end{abstract}

Key words : Identification, Javan Langur (Trachypithecus auratus), D-loop, Javan Langur Center

\section{INTRODUCTION}

Indonesia is one of countries which possesses the richest various species of primates in the world. One of endemic animals lives in Indonesia is Javan Langur (Trachypithecus auratus). Morphological differences and geographical distribution made Javan Langur separated into 2 distinct subspecies (Kurniawan: Personal Communication, 2013). Based on Rosenblum et al. (1997) and Douglas (2004), Trachypithecus auratus is group into 2 subspecies those are Trachypithecus auratus mauritius which distributed in West Java and Trachypithecus auratus auratus which distributed in Bali, Lombok, and East Java. The differences between $T$. a. auratus and T. a. mauritius are the fur color, male genital organ, and face shape (Figure 1). International Union for Conservation of Nature (IUCN) Red List version 2009.2 in 2009 included Javan Langur to Vulnerable category (IUCN, 2009). The importance of determination between T. a. auratus and T. a. mauritius is related to inbreeding grouping, mapping, and determination of natural habitat for releasing. Identification of $T$. a. auratus and T. a. mauritius in JLC is done based on morphological characteristics only, therefore it needs to know the phylogenetic position to support the morphological data. $D$ Loop sequence is a mitochondrial gene (11), which has mutation rate 4-5 time faster than

ISSN 2413-0877 (C) 2015 The Authors.

Published by KnowledgeE Publishing Services This is an open access article under the CC BY-NC-ND license (http://creativecommons.org/licenses/by-nc-nd/4.0) 
other sequences in mitochondrial DNA (Horai et al., 1993). The length of $D$-loop sequence is around $1 \mathrm{~kb}$, and it belongs to non-coding area (Arif \& Khan, 2009). This research aimed to reveal the taxonomic position of Javan Langur (Trachypitecus auratus) in Javan Langur Centerby $D$-loop sequence.

A

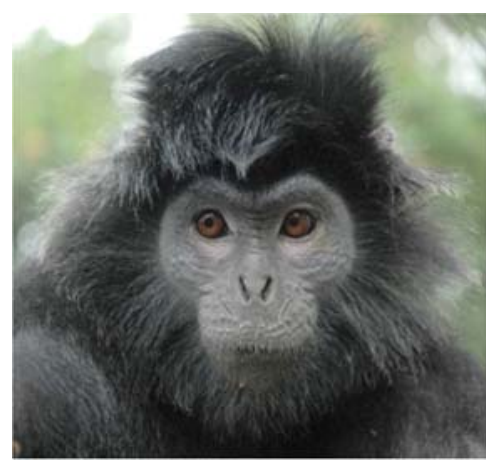

B

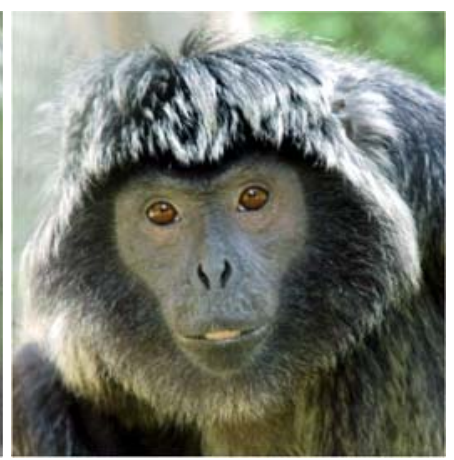

Figure 1. A. Male of Trachypithecus auratus mauritius, B. Male of Trachypithecus auratus auratus (Kurniawan, 2012)

\section{MATERIALS AND METHODS}

Material used in this research is blood sample of Javan Langur provided by Javan Langur Center, from adult females named Embun and ljem. These samples was selected by reason of its morphological characteristic which are assumed as T. a. auratus for Embun, and T. a. mauritius for ljem.

\section{Blood Sampling}

Total DNA isolation was conducted according to Roche Isolation DNA Mini Kit with some modification. D-loop amplification was done by mean of using $D$-loopRs forward 5'GTA CTT AAC TCC ACC ACC AA -3' and D-loopRs reverse 5'- GTT GAG TTG GGT ATG CT GA-3' primers pair in cycle determined. DNA sequencing was performed in Eijkman Institute for Molecular Biology, Jakarta.

\section{RESULTS AND DISCUSSION}

PCR amplification resulted around 350 bp length fragment a 377 bp length fragmentfor ljem and 370 bp for Embun. BLAST analysis result shows that $D$-loop fragment of ljem's sample which has query coverage value $98-100 \%$ with maximum identity value $83-92 \%$ and Embun's sample has query coverage value $90-100 \%$ with maximum identity value 82 $90 \%$ compared to $D$-loop sequence in references species. Query coverage and maximum identity value on both samples almost reach $100 \%$, this shows that $D$-loop sequence obtained from both samples is indeed $D$-loop sequence (Golding et al., 2012).

Clustal $X$ analysis shows that $D$-loop sequence on both samples cannot be compared to Trachypithecus auratus sice there is no reported in NCBI, therefore it can only be compared to other species, those are Trachypithecus cristatus, Trachypithecus poliocephalus, Trachypithecus poliocephalus leucocephalus, Trachypithecus laotum, and Trachypithecus francoisi. 


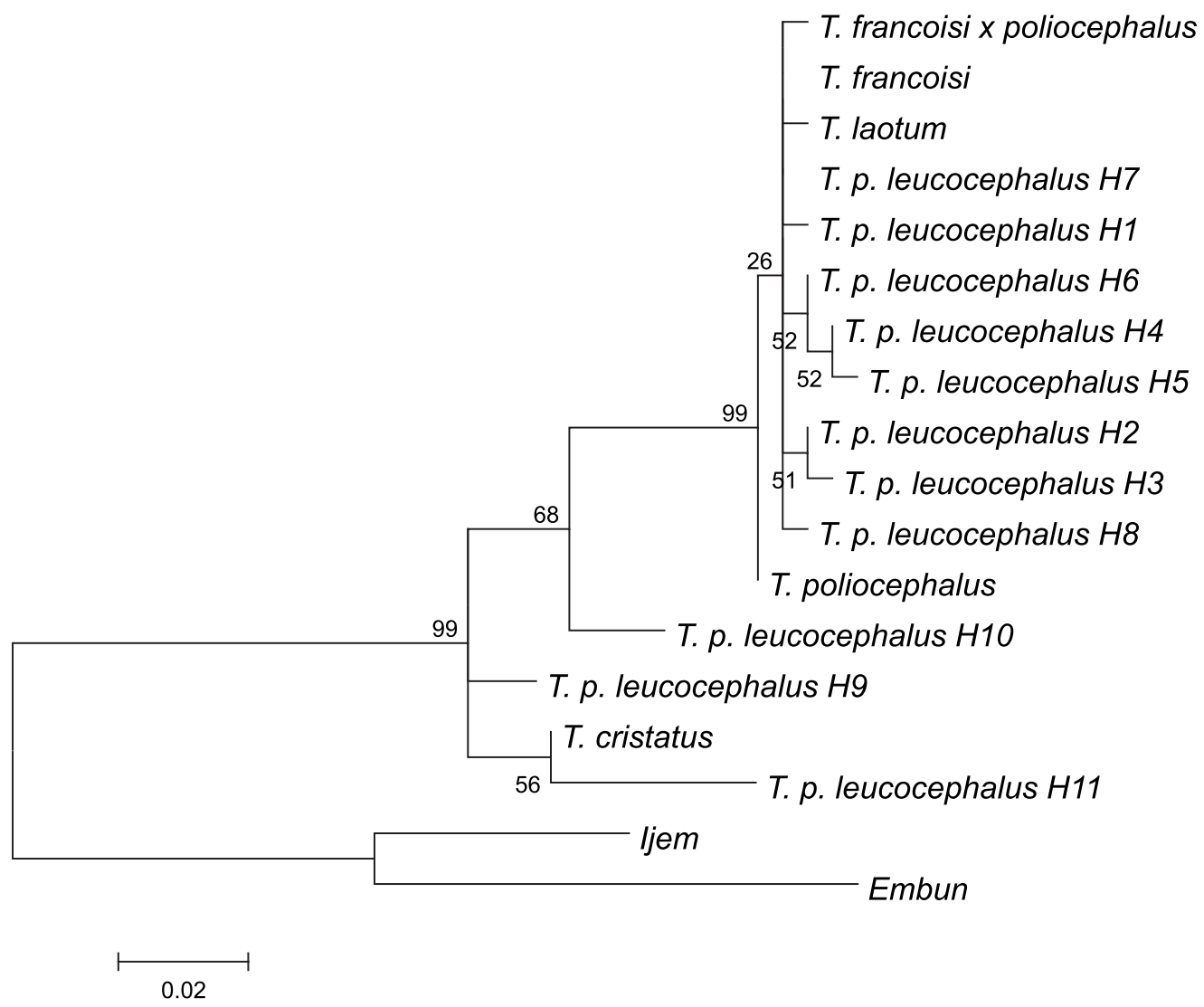

Figure 2. Phylogenetic Tree Utilizing Maximum Likelihood Method, PairwiseDistance Analysis with Kimura-2 Parameter Model

The reconstruction of phylogenetic tree using Maximum Likelihood in 1000 bootstrap resulted on separated clade of ljem and Embun from all references (Figure 2). It is supported the morphological determination that two samples are not belongs to references species (Aggarwal et al., 2007). It is also supported a previous research which reported that ljem belongs to Trachypithecus auratus mauritius while Embun is belongs to Trachypithecus auratus auratus based on Cyt-b sequence (Sakti, 2011).

Genetic distance between ljem and Embun is $11.4 \%$ (Table 2). It is clarify that ljem and Embun belongs to since genetic distance higher than 1,9\% (13) indicated the interspecies relationship between/among samples.

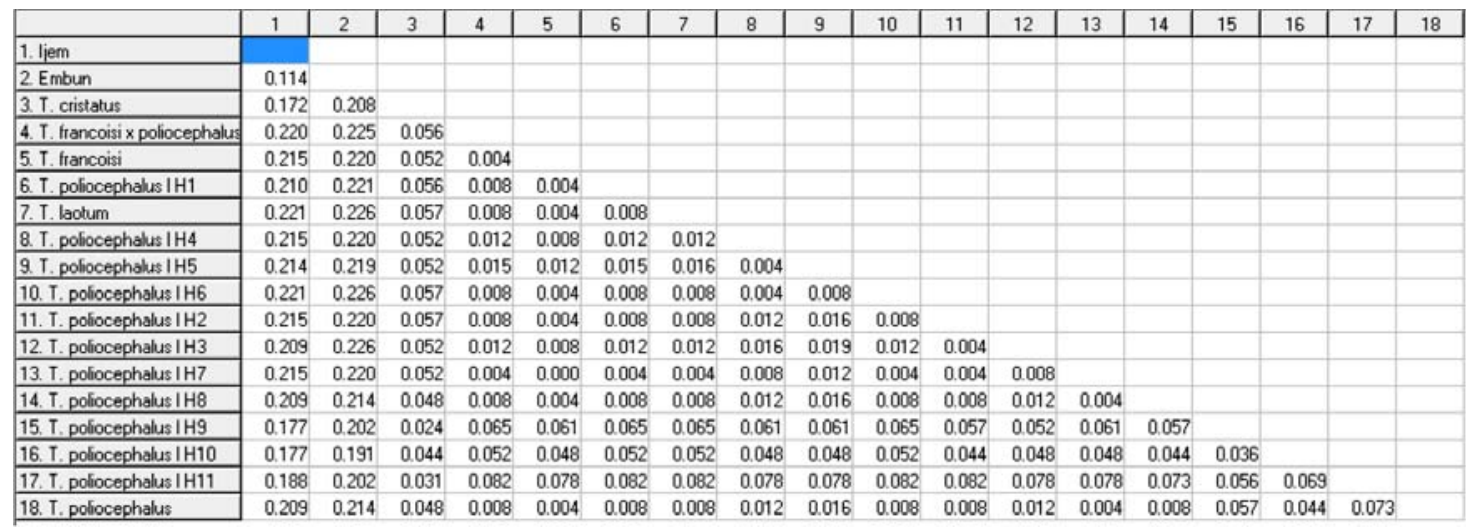

Table 2. Table of Genetic Distance from Samples Used 


\section{REFERENCES :}

Aggarwal, R.K., T. Kivisild, J. Ramadevi, and L. Singh, L. 2007. Mitochondrial DNA Coding Region Sequences Support The Phylogenetic Distinction of Two Indian Wolf Species. J. Zool. Syst. Evol. Res. 45(2): 163-172.

Alamendah. 2010. Lutung Jawa (Trachypithecus auratus). http://alamendah.wordpress.com/ 2010/07/13/lutung-jawa-Trachypithecus-auratus/, accessed 1 June 2011.

Arif, I.A., and H.A. Khan. 2009. Molecular Marker for Biodiversity Analysis of Wildlife Animal: a brief review. Animal Biodiversity and Conservation, 32(1): $9-17$.

Brandon-Jones, D. 2004. A taxonomic Revision of the Langur and Leaf Monkeys (Primates: Colobinae) of South Asia. Zoos' Print Journal 19(8): 1552-1594.

Horai, S., R. Kondo, Y. Nakagawa-Hattori, S. Hayashi, S. Sonada, S., and K. Tajimaas. 1993. Peopling of the Americas, founded by four mayor lineages of Mitochondrial DNA. Mol. Biol. Evol. 10: 23 - 47.

IUCN. 2009. Javan Langur (Trachypithecus auratus). http://www.iucnredlist.org/, accessed 3 June 2011.

Kocher, T. D., W.K. Thomas, A. Meyer, S.V. Edwards, S. Paabo, F.X. Villablanca, and A.C. Wilson. 1989. Dinamics of Mitochondria DNA Evolution in Animals: Amplification and Sequencing with Conserve Primers. Proceeding of the National Academy of Science of the United States of america. $86: 6196-6200$.

Kurniawan, I. 2013. Personal Communication.

Rosenblum, L.L., J. Supriatna, M.N. Hasan, and D.J. Melnick. 1997. High Mitochondrial DNA Diversity with Little Structure Within and Among Leaf Monkey Population (Trachypithecus cristatus and Trachypithecus auratus). International Journal of Primatology. 18 (6) : 1005-1028.

Sakti, M.A.E. 2011. Keragaman Genetik Lutung Jawa (Trachypithecus auratus Geoffroy 1812) di Pusat Rehabilitasi Javan Langur Conservation Program Berdasarkan Gen Cyt B. Master's Thesis. Malang : Program Pascasarjana Universitas Brawijaya.

Statham, M.J., N.T. Lyudmila, B.N. Sacks, A.V. Kharlamova, I.N. Oskina, R.G. Gulevich, J.L. Johnson, S.V. Temnykh, G.M. Acland, and A.V. Kukekova. 2011. On the Origin of a Domesticated Species: Identifying the Parent Population of Russian Silver Foxes (Vulpes vulpes). Biological Journal of the Linnean Society 2:1-8.

Supriatna, J., and E.H. Wahono. 2000. Panduan Lapangan Primata Indonesia. Jakarta : Yayasan Obor Indonesia.

Warren, S.K., J.E. Versscoor, S. Langenhuijzen, Heriyanto, A.R. Swan, L. Vn vaigilant, and L.J. Heeney. 2001. Speciation and Intrasubspecific Variation of Bornean Orangutans, Pongo pygmaeus pygmaeus. Mol. Biol. Evol. 18(4): 472-480 